\title{
Perception regarding Sexuality, Contraceptive and Teenage Pregnancy among Adolescent Studying in Secondary Schools in Palpa District
}

\section{Manju Nepal}

Assistant Professor, Patan Academy of Health Sciences (PAHS), School of Nursing and Midwifery, Lalitpur Nursing Campus, Sanepa, Nepal

Email: nepalmanju2018@gmail.com

\section{Susan Maharjan}

Assistant Professor, PAHS, School of Nursing and Midwifery, Lalitpur Nursing Campus, Sanepa, Nepal

Email: susanaims@hotmail.com

\section{Bimala Adhikari}

Lecturer, PAHS, School of Nursing and Midwifery, Lalitpur Nursing Campaus, Sanepa, Nepald Email: ojaswimk@gmail.com

\section{Laxmi Khanal}

Lecturer, Norvic Institute of Nursing Education, Kathmandu

Email: laxmikhana19@yahoo.com

\section{Parbati Nepal}

Assistant Professor, Lumbini Medical College and Teaching Hospital Tansen, Palpa

Email: kirparu@gmail.com

Correspondence: Manju Nepal, Assistant Professor, Patan Academy of Health Sciences, School of Nursing and Midwifery, Lalitpur Nursing Campus, Sanepa, Nepal

E-mail: nepalmanju2018@gmail.com

Received: April 05, 2021; Revised \& Accepted: April 15, 2021; Published: June 30, 2021

(C) Copyright: Nepal (2021). 


\begin{abstract}
Adolescence is a period of both opportunities and threats. It is also a phase in life marked by vulnerability to risky sexual behavior and underprivileged reproductive health outcomes. The objective of this study was to assess the perception regarding sexuality, contraceptive and teenage pregnancy among adolescents studying in secondary schools in Palpa District. A cross sectional analytical study designed was applied. Total enumerative sampling technique was used to select 407 schools going adolescents in four selected school in Palpa district. Data was collected using self-administered questionnaire. Analysis was done using descriptive and inferential statistics with SPSS version 20. Findings showed that $56.51 \%$ of adolescents had favorable perception on sexuality, 51.84\% of adolescents had favorable perception on contraceptive and $55.77 \%$ had favorable perception on teenage pregnancy. There were significant association between Sex, Grade, Ethnicity, Type of family of adolescent and level of perception on sexuality, contraceptive and teenage pregnancy where Chi-square p value is less than .05 at 5\% level of significance. Based on the findings of the study, majority of adolescents had favorable perception towards sexuality, contraceptive and teenage pregnancy which suggests that adolescents were aware on sexuality, contraceptive and teenage pregnancy.
\end{abstract}

Key words: Adolescent, Contraceptive, Perception, Sexuality, Teenage Pregnancy

\title{
INTRODUCTION
}

Adolescents are individuals between the 10-19 years age groups. This is the transition period from childhood to adulthood which involves dramatic physical, sexual, psychological and social developmental changes which poses risks to their health and wellbeing (World Health Organization $\{\mathrm{WHO}\}, 2018)$. Adolescence pregnancy continues to be a complex and challenging issue for families, health workers, educators, societies and governments, and adolescents themselves (WHO, 2014; \& United Nations Population Fund \{UNFPA\}, 2015).

Adolescents are prone to have many developmental issues, including early sexual debut, risky sexual behaviours, sexually transmitted infections, teenage pregnancy and abortions. These challenges could be worse among adolescents who lack the understanding of sexuality, contraceptive and consequences of teenage pregnancy (Scott-Ashley, Akande, Adebayo \& Iken, 2020).

Perception on sexuality is subjective experiences; it includes biological and psychological as well as social and cultural dimensions of sexual identity and sexual behavior. Adolescents, in all cultures, experience sexuality in diverse ways. The concept of sexuality includes not only sexual identities, sexual norms, sexual practices and behaviours, but also feelings, desires, fantasies and experiences related to sexual awareness, arousal and sexual acts within heterosexual as well as homosexual relations (Gupta, Mishra \& Prabha, 2013). During the adolescence period, there is increasing sexual urge in combination with the unfamiliar, 
mysterious emotions and thoughts which may possibly leads to unmarried pregnancy among adolescents (Papathanasiou, Lahana, 2019). Adolescent girls are coerced into unwanted sex or marriage, which leads to them at risk of unwanted pregnancies, unsafe abortions, sexually transmitted infections (STIs) including HIV, and complications during childbirth. In our neighbor country; India, about $22 \%$ of adolescent girls had experienced pre-marital sex (Ahuja, Patnaik, Gurchandandeep, Lugani, Sharma, Goyal \& Singh, 2019).

Risky sexual behaviours exposes young people to the risk of infection with HIV and other sexually transmitted infections (STIs). Sexual behaviours like unprotected sex, early sexual debut, using alcohol or drugs before sexual intercourse, multiple sexual partners, sexual intercourse for reward, non-use of condom, patronage of commercial sex workers increases the vulnerability of this age group (Okafor, Ada, Azuike, 2018).

Unsafe abortion is common practice among adolescents. Poverty, peer pressure, and living in a single family are the main reasons of teen age pregnancy (Envuladu, Anke, Zwanikken, Zoakah, 2017; Tchokossa, \& Adeyemi, 2018; \& Ajewole, Fasoro, Oluwadare, Agboola, Asubiojo, 2017) Perception on sexuality and contraception was found poor among adolescents. Adolescents are still perceived that contraceptives are only for married couples. Majority of adolescents did not know that only one sexual intercourse is possible to become pregnant (Osaikhuwuomwan, Osemwenkha, 2013; McManus, Dhar, 2008; Kumar, Goyal, Singh, Bhardwaj, Mittal, Yadav, 2017; \& Sah, Gaurav, Baral, Jha, \& Pokharel, 2013).

A descriptive cross sectional study was conducted among 385 adolescents studying in higher secondary schools on perceived behavior and practices of adolescents on sexual and reproductive health and associated factors in Kathmandu. The results showed that less than one quarter $(22.9 \%)$ of adolescents involved in premarital sexual relation, among them (88), 75 $(85.2 \%)$ participants have only one sex partner and $13(14.8 \%)$ participants have two and more sex partners, 66 (75\%) of them use contraceptive method (Poudel \& Poudel, 2014).

Teenage pregnancy is a social threat and common public health problem. It is detrimental to both mother and child because teenage mother is not physically, psychologically and economically ready to bear a child. This phenomenon has multiple adverse consequences on maternal health, child health and overall wellbeing of the society (Mgbokwere, Esienumoh, \& Uyana, 2015). Two percent of Nepalese women aged 25-49 had given birth by the age of 15, while $23 \%$ had their first birth by age 18 (Ministry of Health and Population, New ERA \& ICF International, 2012). So this study aims to identify the perception on sexuality, contraceptive and teen age pregnancy among high school level adolescents.

\section{OBJECTIVE}

The objective of this study is to identify the perception on sexuality, contraceptive and teen age pregnancy among adolescents studying in secondary school in Palpa Distric. 


\section{METHODOLOGY}

A cross sectional analytical study design was adopted to select 407 school going adolescents in four secondary schools in Palpa district. The selected adolescents were between the age of 13 and 19 years. The study was conducted in Tansen Municipality, Palpa district. It is located in western Nepal. Non probability, convenient sampling technique was used to select 407 schools going adolescents studying in grade 9 and 10 in four selected schools namely Shree Saraswati Seconday School, Shree Damkada Secondary School, Shree Sharada Secodary School and Shree Mandali Secondary School of Tansen Municicipality.

A structured self-administered questionnaire was developed on the basis of extensive review of literature to find out the perception on sexuality, contraceptive and teenage pregnancy among adolescent. The research instrument consisted of two parts: Part I was related to demographic characteristics (age, sex, grade, ethnicity, religion, type of family, parental education, parental occupation and parental type of marriage). Part II consisted of 5 points Likert scale which identified the perception on sexuality, contraceptive and teenage pregnancy.

\section{Scoring criteria}

Perception on sexuality and contraceptive had 9 questions in each discipline and its total score ranged between 0-45 in each discipline. Perception on teenage pregnancy had 10 questions and its total score ranged between 0-50. Mean was calculated from the total score of perception on sexuality, contraceptive and teenage pregnancy. The score equal to mean and above mean was categorized as favorable perception and the score below the mean was categorized as unfavorable perception on sexuality, contraceptive and teenage pregnancy.

\section{Validity and reliability of the instrument}

The content validity of the instrument was established by consultation with subject experts. Pretesting of the instrument was done among 41 adolescents in similar setting. Necessary modification was done after its result. Reliability of the instrument was tested using Chronbach's alpha coefficient for perception on sexuality, contraceptive and teenage pregnancy related statements which gave the satisfactory value of .72 .

Data was collected after getting ethical approval from Nepal Health Research Council. Data was collected through self-administered questionnaire on Nepali version. Necessary instructions were given to adolescents studying in grade 9 and 10 before administering the questionnaire and data was collected in classroom setting. The respondents were assured that their participation in this study was voluntary and also informed that they could leave the study anytime if they wished to do so. At first data was collected at Shree Mandali Secondary School on 2076/1/17, at Sharadha Secondary School on 2076/2/20, at Shree Saraswati Secondary School on 2076/03/02 and Shree Damkada Secondary School on 2076/3/25.

Confidentiality was maintained by keeping the data source protected by the researcher through proper storage of the filled instruments and through use of code numbers instead of the names in transferring the data from questionnaire to data sheet. After collecting data, informal 
discussion on the subject matter was done especially on sexuality and contraceptive. The data was analyzed by using the Statistical Package for Social Science (SPSS) version 20. The descriptive statistics such as frequency distribution, percentage, mean and standard deviation were calculated. Inferential statistics such as chi-square test was used at $p$ value less than .05 at $5 \%$ level of significance.

\section{RESULTS:}

Regarding the socio-demographic data, the result of this study shows that majority of respondents (58.97\%) were early adolescent. Out of 407 adolescents, majority of them $(58.50 \%)$ studying in grade 9 . Nearly similar representation of male $(50.37 \%)$ and female $(49.63 \%)$ adolescents were observed. The higher percentages (34.15\%) of respondents were from Dalit Ethnicity. Almost all (98\%) were Hindu and about half of respondents (51.60\%) were living in single family.

Table 1. Distribution of frequency and percentage regarding perception on sexuality among adolescents

\begin{tabular}{|c|c|c|c|c|c|}
\hline Perception on Sexuality & $\begin{array}{l}\text { Strongly } \\
\text { agree } \\
\text { N }(\%)\end{array}$ & $\begin{array}{l}\text { Agree } \\
\mathbf{N}(\%)\end{array}$ & $\begin{array}{l}\text { Uncertain } \\
\mathbf{N}(\%)\end{array}$ & $\begin{array}{l}\text { Disagree } \\
\mathrm{N}(\%)\end{array}$ & $\begin{array}{l}\quad n=407 \\
\text { Strongly } \\
\text { Disagree } \\
\mathbf{N}(\%)\end{array}$ \\
\hline $\begin{array}{l}\text { 1. Teenagers should not be physically } \\
\text { grown to have a sexual relation }\end{array}$ & $334(82.06)$ & $54(13.27)$ & $6(1.47)$ & $5(1.23)$ & $8(1.97)$ \\
\hline $\begin{array}{l}\text { 2. Sexual relation since teenagers do not } \\
\text { cause any reproductive health problems }{ }^{\alpha}\end{array}$ & $4(0.98)$ & - & $17(4.18)$ & $23(5.65)$ & $363(89.19)$ \\
\hline $\begin{array}{l}\text { 3. Curiosity encourages adolescent's } \\
\text { sexual activity }\end{array}$ & $29(7.12)$ & $3(0.74)$ & $84(20.64)$ & )$^{47(11.55}$ & $244(59.95)$ \\
\hline $\begin{array}{l}\text { 4. Teenager should permit for sexual } \\
\text { relation if their pairs demands for relation }\end{array}$ & $29(7.13)$ & $29(7.13)$ & $24(5.89)$ & $\begin{array}{l}49(12.04 \\
)\end{array}$ & $276(67.81)$ \\
\hline $\begin{array}{l}\text { 5. If teenagers permit sexual relation, their } \\
\text { pair would be more committed to them for } \\
\text { marriage }^{\alpha}\end{array}$ & $263(64.62)$ & $16(3.93)$ & $48(11.79)$ & $19(4.67)$ & 61(14.99) \\
\hline $\begin{array}{l}\text { 6. Teenager would be lonely if they do not } \\
\text { permit sexual relation }\end{array}$ & $32(7.86)$ & $60(14.74)$ & $15(3.69)$ & )$^{47(11.55}$ & $253(62.16)$ \\
\hline $\begin{array}{l}\text { 7. If teenagers permit sexual relation, they } \\
\text { have got intimate friends }{ }^{\alpha}\end{array}$ & $20(4.91)$ & $67(16.46)$ & $39(9.58)$ & $\begin{array}{l}73(17.94 \\
)\end{array}$ & $208(51.11)$ \\
\hline $\begin{array}{l}\text { 8. Those who have multiple sexual } \\
\text { partners, there may have the chance of } \\
\text { having sexually transmitted infection }\end{array}$ & 402(98.77) & $3(0.74)$ & $2(0.49)$ & - & -- \\
\hline $\begin{array}{l}\text { 9. Sex education encourage teenager to } \\
\text { have sexual relation }^{\alpha}\end{array}$ & $30(7.37)$ & $30(7.37)$ & $66(16.22)$ & $14(3.44)$ & $267(65.60)$ \\
\hline
\end{tabular}

\section{Note ${ }^{\alpha}$ denote negative statement.}

Regarding sexuality, finding shows that $98.77 \%$ of respondents strongly agreed that there may have the chance of sexually transmitted infection who have multiple sexual partners. Most 
of the respondents $(89.19 \%)$ strongly disagreed on the statement that sexual relation since teenage do not cause any reproductive health problems (Table 1).

Table 2. Distribution of frequency and percentage regarding perception on contraceptiveamong adolescents

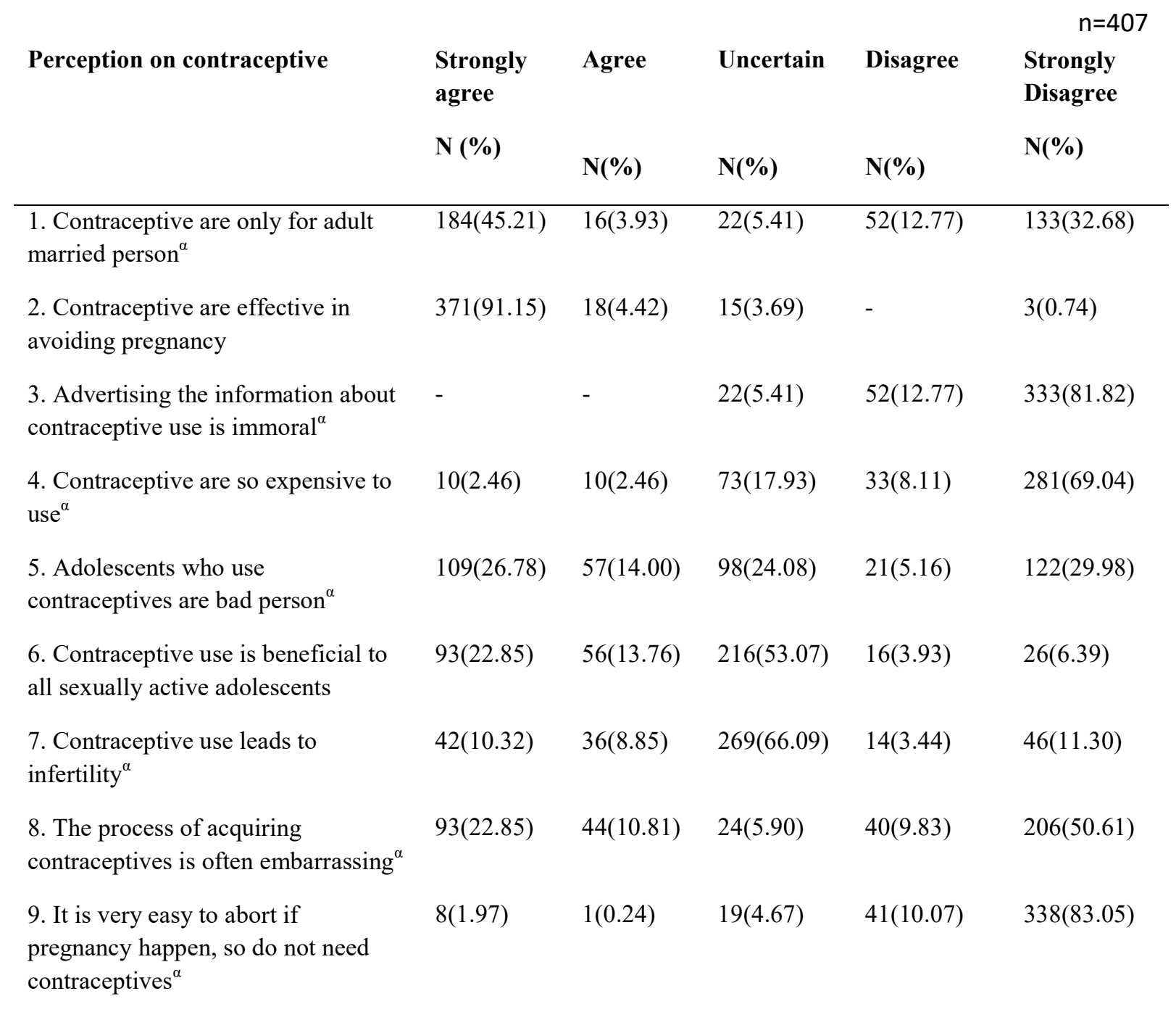

\section{Note ${ }^{\alpha}$ denote negative statement.}

Regarding the contraceptive, $91.15 \%$ of respondents strongly agreed that contraceptive was effective in avoiding pregnancy. Similarly, $83.05 \%$ of respondents strongly disagreed on the statement that there was very easy to abort the pregnancy, so they did not feel necessary of contraceptives (Table 2). 
Table 3. Distribution of frequency and percentage regarding perception on teenage pregnancy among adolescents

\begin{tabular}{|c|c|c|c|c|c|}
\hline Perception on teenage pregnancy & $\begin{array}{l}\text { Strongly } \\
\text { agree } \\
\text { N (\%) }\end{array}$ & $\begin{array}{l}\text { Agree } \\
\mathrm{N}(\%)\end{array}$ & Uncertain & $\begin{array}{l}\text { Disagree } \\
\mathbf{N}(\%)\end{array}$ & $\begin{array}{l}\mathrm{n}=407 \\
\text { Strongly } \\
\text { Disagree } \\
\mathbf{N}(\%)\end{array}$ \\
\hline $\begin{array}{l}\text { 1. Teenager female are physically and } \\
\text { mentally prepare for pregnancy }\end{array}$ & - & $20(4.91)$ & $9(2.21)$ & $40(9.83)$ & $338(83.05)$ \\
\hline $\begin{array}{l}\text { 2. Teenage pregnancy are due to the } \\
\text { teenage girls mistake }{ }^{\alpha}\end{array}$ & $45(11.06)$ & $30(7.37)$ & $5(1.23)$ & $34(8.35)$ & 293(71.99) \\
\hline $\begin{array}{l}\text { 3. If teenager girl gives birth; she may } \\
\text { face physical, psychological, social and } \\
\text { financial problems }\end{array}$ & $338(83.05)$ & $45(11.06)$ & $24(5.89)$ & - & - \\
\hline $\begin{array}{l}\text { 4. Teenage mother rear her child along } \\
\text { with her growth }\end{array}$ & 293(71.99) & $53(13.02)$ & $61(14.99)$ & - & -- \\
\hline $\begin{array}{l}\text { 5. Teenage pregnant mother can } \\
\text { continue her education }\end{array}$ & $16(3.93)$ & $39(9.58)$ & $299(73.47)$ & $32(7.86)$ & $21(5.16)$ \\
\hline $\begin{array}{l}\text { 6. Teenage pregnancy increase maternal } \\
\text { morbidity and mortality }\end{array}$ & $376(92.39)$ & $27(6.63)$ & $4(0.98)$ & - & - \\
\hline $\begin{array}{l}\text { 7. Teenage pregnant mother give health } \\
\text { baby }^{\alpha}\end{array}$ & $10(2.46)$ & $38(9.34)$ & $127(31.20)$ & $35(8.60)$ & 197(48.40) \\
\hline $\begin{array}{l}\text { 8. Teenage pregnancy prevents girls' } \\
\text { possibilities for exercising the rights to } \\
\text { education, health and employment }\end{array}$ & $298(73.23)$ & $27(6.63)$ & $44(10.81)$ & $25(6.14)$ & 13(3.19) \\
\hline $\begin{array}{l}\text { 9. Easily availability and accessibility of } \\
\text { contraceptive can decrease teenage } \\
\text { pregnancy }\end{array}$ & $354(86.98)$ & $34(8.35)$ & $19(4.67)$ & - & - \\
\hline $\begin{array}{l}\text { 10. Adolescent male should also engage } \\
\text { in teenage pregnancy prevention } \\
\text { program }\end{array}$ & $363(89.19)$ & $36(8.85)$ & $4(0.98)$ & $4(0.98)$ & - \\
\hline
\end{tabular}

Note ${ }^{\alpha}$ denote negative statement.

Table 3 shows the perception regarding teenage pregnancy, 92.39\% of respondents strongly agreed that teenage pregnancy increased maternal morbidity and mortality. The $89.19 \%$ of respondents strongly agreed that adolescent males were also engaged in teenage pregnancy prevention program. 
Table 4. Respondents' Perception on Sexuality, Contraceptive and Teenage Pregnancy

$$
\mathrm{n}=407
$$

\begin{tabular}{lll} 
Characteristics & Number & Percentage \\
\hline Sexuality & 230 & 56.51 \\
Favorable perception & 177 & 43.49 \\
Unfavorable Perception & & \\
Mean score \pm SD= $\mathbf{3 7 . 0 8} \pm \mathbf{5 . 2 2}$ & & 51.84 \\
Contraceptive & 211 & 48.16 \\
Favorable perception & 196 & \\
Unfavorable perception & & 55.77 \\
Mean score \pm SD $=\mathbf{3 4 . 4 7} \pm \mathbf{4 . 5 7}$ & & 44.23 \\
Teenage pregnancy & 227 & \\
Favorable perception & 180 & \\
Unfavorable perception & & \\
Mean score \pm SD $=\mathbf{4 4 . 1 8} \pm \mathbf{4 . 1 7}$ &
\end{tabular}

More than half of respondents 230 (56.51\%) had favorable perception on sexuality. Similarly 211 (51.84\%) of respondents had favorable perception on contraceptive and 227 $(55.77 \%)$ had favorable perception on teenage pregnancy (Table 4$)$.

Table 3. Respondents' Overall Perception on Sexuality, Contraceptive and Teenage Pregnancy

\begin{tabular}{cll} 
Overall Perception & Number & \multicolumn{2}{c}{$\mathrm{n}=407$} \\
\hline Favorable perception & 265 & 65.11 \\
Male & 152 & 37.35 \\
Female & 113 & 27.76 \\
Unfavorable Perception & 142 & 34.89 \\
Male & 53 & 13.02 \\
Female & 89 & 21.87 \\
\hline
\end{tabular}

Table 5 depicts the respondents' overall perception of on sexuality, contraceptive and teenage pregnancy where majority of the respondents $265(65.11 \%)$ had favorable perception on sexuality, contraceptive and teenage pregnancy.

Table 6. Association of demographic variables with perception of sexuality, contraceptive and teenage pregnancy 


$$
\mathrm{n}=\mathbf{4 0 7}
$$

Level of perception

\begin{tabular}{|c|c|c|c|c|}
\hline Socio-demographic variables & $\begin{array}{l}\text { Favorable perception } \\
\mathrm{N}(\%)\end{array}$ & $\begin{array}{l}\text { Unfavorable } \\
\text { perception N(\%) }\end{array}$ & Chi-square & p-value \\
\hline \multicolumn{5}{|l|}{ Sex of adolescent } \\
\hline Male & $152(74.15)$ & $53(25.85)$ & 14.84 & .000 \\
\hline Female & $113(55.94)$ & $89(44.06)$ & & \\
\hline \multicolumn{5}{|l|}{ Grade of adolescent } \\
\hline 9 & $136(57.14)$ & $102(42.86)$ & 16.018 & .000 \\
\hline 10 & $129(76.33)$ & $40(23.67)$ & & \\
\hline \multicolumn{5}{|l|}{ Ethnicity } \\
\hline Bhramin and Chhetri & $116(76.32)$ & $36(23.68)$ & 13.409 & .000 \\
\hline Others & $149(58.43)$ & $106(41.57)$ & & \\
\hline \multicolumn{5}{|l|}{ Type of family } \\
\hline Single & $153(72.86)$ & $57(27.14)$ & 11.461 & .001 \\
\hline Joint & $112(56.85)$ & $85(43.15)$ & & \\
\hline \multicolumn{5}{|l|}{ Literacy status of Father } \\
\hline Literate & $231(64.71)$ & $126(35.29)$ & 2.09 & .752 \\
\hline Illiterate & $34(68)$ & $16(32)$ & & \\
\hline \multicolumn{5}{|l|}{ Literacy status of Mother } \\
\hline Literate & $220(63.58)$ & $126(36.42)$ & 2.369 & .146 \\
\hline Illiterate & $45(73.77)$ & $16(26.27)$ & & \\
\hline \multicolumn{5}{|l|}{ Parental type of marriage } \\
\hline Love marriage & $39(9.58)$ & $27(6.63)$ & 1.257 & .263 \\
\hline Arrange marriage & $226(55.53)$ & $115(28.26)$ & & \\
\hline
\end{tabular}

There were significant association between Sex, Grade, Ethnicity, Type of family of adolescents and level of perception on sexuality, contraceptive and teenage pregnancy $\left(\chi^{2}=\right.$ 14.84 $\mathrm{P}=.000, \chi^{2}=16.01 \mathrm{P}=.000, \chi^{2}=13.40 \mathrm{P}=.000, \chi^{2}=11.46 \mathrm{P}=.001$ respectively) whereas, literacy status of father and mother and parental type of marriage had not significantly associated with level of perception on sexuality, contraceptive and teenage pregnancy (Table 6).

\section{DISCUSSION}

The overall perception on sexuality of respondents $(56.51 \%)$ was found to have favorable perception in this study. Regarding the sexuality most of the respondents $(98.77 \%)$ perceived that those who have multiple sexual partners may have the chance of sexually transmitted infection. Majority of the respondents (89.19\%) negatively perceived that sexual relation since teenagers do not cause any reproductive health problem. Similarly, 334(82.06\%) respondents strongly agreed on teenagers should not be physically grown to have a sexual relation. On the statement curiosity encourages adolescents' sexual activity; 244(59.95\%) respondents strongly disagreed. By this response it is understood that adolescents were not aware about their curiosity. Regarding the statement about whether a teenager should be permitted for sexual relation if their pairs demands for sexual relation $276(67.81 \%)$ respondents strongly disagreed, similarly 
$263(64.62 \%)$ respondents strongly agreed that if teenagers were permitted for sexual relation, their pair would be more committed to them for marriage.

Respondents were against having multiple sexual partners as this is understood from result where 263(64.62\%) respondents strongly agreed that if teenagers were permitted for sexual relation, their pair would be more committed to them for marriage. Similarly respondents perception on the statement; teenager would be lonely if they were not permitted for sexual relation, the result showed that 253(62.16\%) strongly disagreed.

Regarding the perception on sexual relation, out of 407 respondents, 208 (51.11\%) strongly disagreed on the statement if teenagers were permitted for sexual relation, they would have intimate friends. More than half of the respondents (65.60\%) strongly agreed that sex education is beneficial for teenager; a similar finding was seen on the need of sex education in a study conductedin Umbala District in India, where most of adolescents (93.5\%) were in favor of sex education (Sah, Gaurav, Baral, \& Jha ,2013). Similarly the findings of a study conducted in Bajhang, Nepal among higher secondary school level students showed that $48 \%$ of the respondents strongly agreed on the necessity of sexual health education to students at schools, $31 \%$ of respondents disagreed on learning about sexual health encourages premarital sex, $33 \%$ strongly agreed on needs of sexual health education for healthy relationship with the opposite sex (Thapa \& Chand SB).

Regarding the perception of contraceptive among adolescents $32.68 \%$ of the respondents strongly disagreed those contraceptives were only for adult married person. This finding is consistent with the findings of a study conducted in South Delhi India where only $32 \%$ thought it should only be taken by married women. Similarly $91.15 \%$ strongly agreed that contraceptive are effective in avoiding pregnancy in this study where as in another study done in India showed that condom is the most common method for youths/adolescents (38.1\%) (Kumar, Goyal, Singh, Bhardwaj, Mittal \&Yadav, 2017).

In this study $69.04 \%$ of the respondents strongly disagreed that contraceptive are so expensive to use, similarly only $29.98 \%$ of the respondents strongly disagreed that adolescents who uses contraceptives are bad person. By this finding it is understood that majority of the adolescents knew about free availability of contraceptives and the use of contraceptive/s before marriage is not bad. The $22.85 \%$ of respondents strongly agreed that contraceptive use is beneficial to all sexually active adolescents where as $11.30 \%, 50.61 \%$ and $83.05 \%$ of respondents strongly disagreed that contraceptive use leads to infertility, the process of acquiring contraceptives is often embarrassing and it is very easy to abort if pregnancy happen, so contraceptive is not needed respectively. This finding contradicts with the findings of a study conducted in Nigeria where $42.9 \%$ had misperceptions about its safety, believing that contraceptives are dangerous and chemicals in contraceptives can damage their reproductive system (Okanlawon, Reeves \& Agbaje, 2010).

In this study half of the respondents $(50.61 \%)$ strongly disagreed on the statement, the process of acquiring contraceptives is often embarrassing this finding is similar with a study 
conducted in Nigeria which showed that $68.7 \%$ of the adolescents felt embarrassed or ashamed to use or purchase condom/contraceptives (Osaikhuwuomwan \& Osemwenkha, 2013). Regarding the perception on teenage pregnancy, in this study $73.47 \%$ of the respondents were uncertain on the statement that teenage pregnant mother can continue her education. This finding is similar with the study conducted in Nigeria where $83.7 \%$ of adolescents perceived that teenage pregnancy prevents from finishing school education (Ajewole, Fasoro, Oluwadare, Agboola \& Asubiojo, 2017).

Regarding the perception on sexuality, contraceptive and teenage pregnancy among adolescents more than half of respondents had favorable perception on sexuality $(56.51 \%)$, contraceptives (51.84\%) and teenage pregnancy (55.77\%).

\section{LIMITATIONS}

The study was conducted only in few schools among adolescents studying in grade 9 and 10 using a non-probability sampling so; the findings of this study cannot be generalized to other setting with confidence.

\section{CONCLUSION}

Based on the identified perceptions of sexuality, contraceptive and teenage pregnancy majority of the respondents had favorable perception. By this study it is concluded that adolescents were aware on sexuality, contraceptive and teenage pregnancy. There were significant association between sex, grade, ethnicity, type of family of adolescent and level of perception on sexuality, contraceptive and teenage pregnancy.

\section{ACKNOWLEDGEMENT}

The authors are deeply indebted to the adolescents participating in this study and parents and principal of schools for providing permission for the conduction of study. Special thanks go to Patan Academy of Health Science, School of Nursing \& Midwifery (Lalitpur Nursing Campus) for encouraging me to do this research. Last but not the least my special thanks goes to statistician Nava Raj Poudel, Ph.D Priscilla Samson and Ph. D. Bimala Panthee for proving support during the study and Nepal Health Research Council (NHRC) Ethical Review Board for providing the ethical approval.

\section{Conflict of interest}

The authors declare no conflict of interest.

\section{REFERENCES}

Ahuja, V, K., Patnaik, S., Gurchandandeep, Lugani, Y., Sharma, N., Goyal, S. \& Singh, G. (2019). Perception and preferences regarding sex and contraception, amongst adolescents. Journal of family medicine and primary care,8(10):3350-3355. Retrieved from https://jfmpc.com/article.asp?issn=2249-4863; year=2019; volume=8; issue $=10 ;$ spage $=3350$; epage $=3355$; aulast $=$ Ahuja; type $=3$ 
Ajewole, I.C.C., Fasoro, A.A., Oluwadare, T., Agboola, A.A. \&Asubiojo, E.A. (2017). Perception of Adolescents in Secondary School in a Rural Community in Southwest Nigeria towards Teenage Pnregnancy. SAS Journal of Medicine,3(2): 36-41. Retrieved from http://eprints.abuad.edu.ng/647/1/SASJM-3236-41.pdf.

Envuladu, E.A., Anke, V.K., Zwanikken, P. \&Zoakah, A.I. (2017).Sexual and Reproductive Health Challenges of Adolescent Males and Females in some Communities of Plateau State Nigeria. International Journal of Psychology and Behavioral Sciences, 7(2): 55-60 DOI: 10.5923/j.ijpbs.20170702.02.

Gupta, M.k., Mishra, C.P. \&Prabha, C. (2013). Perception regarding sexuality among adolescent girls: a community based study from rural India. Indian Journal of Preventive and Social Medicine,44(1):64-73. Retrieved from https://www.researchgate.net/publication/277391768_PERCEPTION_REGARDING_SEX UALITY_AMONG_ADOLESCENT_GIRLS_A_COMMUNITY_BASED_STUDY_FROM_RURAL_I NDIA

Kumar, R., Goyal, A., Singh, P., Bhardwaj, A., Mittal, A. \&Yadav, S.S. (2017).Knowledge Attitude and Perception of Sex Education among School Going Adolescents in Ambala District, Haryana, India: A Cross-Sectional Study. Journal of Clinical and Diagnostic Research, 11 (3): doi: 10.7860/JCDR/2017/19290.9338. Retrieved from https://www.ncbi.nlm.nih.gov/pmc/articles/PMC5427339/

McManus, A. \&Dhar, L. (2008). Study of knowledge, perception and attitude of adolescent girls towards STIs/HIV, safer sex and sex education: (A cross sectional survey of urban adolescent school girls in South Delhi, India). BioMed Central, BMC Women's Health,8(1)2 doi:10.1186/1472-6874-8-12. Retrieved from file://C:/Users/Uk/Downloads/1472-6874-8-12.pdf

Mgbokwere, O.D., Esienumoh, E.E., \&Uyana, D.A. (2015). Perception and attitude of parents towards teenage pregnancy in a rural community of cross river state Nigeria. Global Journal of Pure and Applied Sciences, 21:181-172.DOI:

http://dx.doi.org/10.4314/gjpas.v21i2.10

Ministry of Health and Population, New ERA \&ICF International. (2012). Nepal Demographic and Health Survey: Key Findings. Kathmandu, Nepal, and Calverton, Maryland, USA: Ministry of Health and Population, New ERA and ICFInternational.

Okafor, K. C., Ada.,V.Y. \&Azuike, E. C. (2018). Risky sexual behavior of young people in an urban community, South - South, Nigeria. Global Journal of Medicine and Public Health, 7(4):1-7. Retrieved from: file://C:/Windows/system32/config/systemprofile/Downloads/GLOBAL_JOURNAL_OF_ MEDICINE_AND_PUBLIC_HE.pdf

Okanlawon, K., Reeves, M. \&Agbaje, O.F. (2010).Contraceptive Use: Knowledge, Perceptions and Attitudes of Refugee Youths in Oru Refugee Camp, Nigeria. African Journal of 
Reproductive Health,14(4): 17-26. Retrieved from http://www.bioline.org.br/pdf?rh10061

Osaikhuwuomwan, J.A. \&Osemwenkha, A.P. (2013).Adolescents' perspective regarding adolescent pregnancy, sexuality and contraception.Asian Pacific Journal of Reproduction, 2(1): 58-62. Retrieved from: https://ac.elscdn.com/S2305050013601189/1-s2.0-S2305050013601189-main.pdf?_tid=261982258 bf5-4e07-822c9a8d72026a4c\&acdnat=1524829675_d0dd371da76e6eb797888393531e8c26

Papathanasiou, I. \&Lahana, E. (2019).Adolescence, sexuality and sexual education.Health Science Journal.1. Retrieve from https://www.hsj.gr/medicine/adolescence-sexualityand-sexual-education.pdf

Poudel, D.P., \& Poudel, L. (2014). Perceived behavior and practices of adolescents on sexual and reproductive health and associated factors in Kathmandu, Nepal. Muller Journal of Medical Sciences and Research, 5(2): 101-112. Retrieved from https://www.mjmsr.net/article.asp?issn=0975-

9727; year=2014; volume=5; issue=2; spage=106; epage=112; aulast=Paudel

Sah, B. R., Gaurav, K., Baral, D. D., Jha, N., \&Pokharel, K. P. (2013). Burden of Teenage Pregnancy in Hilly Area of Eastern Region of Nepal.Journal of Nobel Medical College,3(1):6. Retrieved from: https://www.researchgate.net/profile/Paras_Pokharel/publication/276807131_Burden _of_Teenage_Pregnancies_in_Hilly_Area_of_Eastern_Region_of_Nepal/links/55f537f90 8ae63926cf2823c.pdf?origin=publication_list

Scott-Ashley, O.T., Akande, S.O., Adebayo, A. M. \&Iken, O.F. (2020). Adolescents' Knowledge of Sexuality and Perceptions Regarding Teenage Pregnancy: A Qualitative Study among Secondary School Students in Ibadan, Southwest Nigeria. International Journal of School Health,7(2):37-45. Retrieved from http://intjsh.sums.ac.ir/article_46565_073d734ef64f29b556f1cdf64be20f67.pdf

Tchokossa, M.A. \&Adeyemi, B.A. (2018).Knowledge and Use of Contraceptives among Female Adolescents in Selected Senior Secondary Schools in Ife Central Local Government of Osun State, Nigeria.International Journal of Caring Sciences, 11 (3):1647. Retrieved from https://www.internationaljournalofcaringsciences.org /docs/36tchokossa_original_11_3.pdf

Thapa, K.B. \& Chand, S.B. (2018). Knowledge and awareness about sexually transmitted infections among higher secondary school students in Bajhang, Nepal. MOJ Public Health,7(3):101-106. doi: 10.15406/mojph.2018.07.00213.

United Nations Population Fund UNFPA, New York, 2015.GIRLHOOD, NOT MOTHERHOOD Preventing Adolescent Pregnancy. Retrieved from 
https://www.unfpa.org/sites/default/files/pubpdf/Girlhood_not_motherhood_final_we b.pdf

WHO.(2014).Adolescent pregnancy. Retrieved from: http://apps.who.int/iris/bitstream/10665/112320/1/WHO_RHR_14.08_eng.pdf

WHO South East Asia.(2018). Adolescent Health and Development. Retrieved from http://www.searo.who.int/entity/child_adolescent/topics/adolescent_health/en/ 